\title{
Human Rights and the 1980 U.S. Presidential Election
}

\section{Rasmus Sinding Søndergaard}

Postdoc, Human Rights Studies, Lund University

\begin{abstract}
Due to dramatic developments in international affairs and the starkly diverging foreign policy visions of the two candidates, Jimmy Carter and Ronald Reagan, foreign policy occupied a usually prominent role in the 1980 U.S. presidential election. A central component of the foreign policy debate was the appropriate role for human rights concerns in American foreign relations. Nevertheless, neither historians of U.S. presidential elections nor historians of human rights have devoted much attention to the issue. This article represents the first comprehensive study of the role of human rights in the 1980 U.S. presidential election. First, it examines the role of human rights in the foreign policy visions of the presidential candidates, focusing especially on Reagan's criticism of Carter's human rights policy. Second, it assesses the impact the issue of human rights had on the 1980 election and the way the 1980 election shaped the role of human rights in U.S. foreign policy.
\end{abstract}

Keywords: U.S. foreign policy, human rights, the 1980 presidential election, Jimmy Carter, Ronald Reagan

Although foreign policy is rarely a dominant theme in U.S. presidential elections, in 1980 dramatic developments in international affairs and the starkly diverging foreign policy visions of the two candidates made foreign policy a salient campaign issue. A central component of the foreign policy debate was the appropriate role for human rights concerns in American foreign relations. The incumbent, President Jimmy Carter, had made human rights the banner for his foreign policy. He had adopted human rights as a language to restore America's moral standing in the world after the Vietnam War and viewed it as a way to break with the Cold War dichotomy of 
East-West contestation. ${ }^{1}$ Conversely, the challenger, Ronald Reagan, made criticism of Carter's human rights policy an integral part of his platform. To Reagan, this policy had proven both misguided and dangerous and he blamed it for weakening America's allies and strengthening its enemies. ${ }^{2}$

Despite the centrality of the concept of human rights in the 1980 U.S. presidential election, the topic has received limited scholarly attention. Historians of U.S. presidential elections have tended to neglect the importance of foreign policy in elections as well as the impact of electoral issues on the formation of foreign policy. This neglect appears particularly problematic in an age of U.S. superpower status where presidential candidates have needed to convince the electorate of their ability to exert leadership on the global stage. Fortunately, recent scholarship has begun to address this omission. ${ }^{3}$ With regards to the 1980 election, the most compressive study is Robert Mason's article on the relationship between domestic politics and war and peace. ${ }^{4}$

Perhaps more surprisingly, the bourgeoning historical literature on human rights in American foreign relations has also largely bypassed the 1980 election. This scholarship has focused predominantly on the role played by the United States in the establishment of human rights in the 1940s and the rediscovery of human rights concerns in American politics in the 1970s. Elizabeth Borgwardt argues that the human rights pinned down in the Universal Declaration of Human Rights (UDHR) were essentially an expanded version of the New Deal and Four Freedoms launched by U.S. President Franklin D. Roosevelt. ${ }^{5}$ Samuel Moyn argues that human rights only truly had their breakthrough in the 1970 s as a morality-based anti-politics, fill-

1 David F. Schmitz and Vanessa Walker, "Jimmy Carter and the Foreign Policy of Human Rights: The Development of a Post-Cold War Foreign Policy,” Diplomatic History 28, no. 1 (2004): 113-43.

2 Carl J. Bon Tempo, "Human Rights and the U.S. Republican Party in the Late 1970s," in The Breakthrough. Human Rights in the 1970s, ed. Jan Eckel and Samuel Moyn (Philadelphia, PA: University of Pennsylvania Press, 2014), 159-63.

3 Michael H. Armacost, Ballots, Bullets, and Bargains : American Foreign Policy and Presidential Elections (New York: Columbia University Press, 2015); Andrew Johnstone and Andrew Priest, eds., US Presidential Elections and Foreign Policy: Candidates, Campaigns, and Global Politics from Fdr to Bill Clinton (Lexington, KY: University Press of Kentucky, 2017).

4 Robert Mason, "The Domestic Politics of War and Peace: Jimmy Carter, Ronald Reagan, and the Election of 1980," in US Presidential Elections and Foreign Policy (Lexington, KY: University Press of Kentucky, 2017).

5 Elizabeth Borgwardt, A New Deal for the World: America's Vision for Human Rights (Cambridge, MA: Harvard University Press, 2005). 
ing the void after the failure of the omnipotent revolutionary agendas of socialism and anti-colonialism. ${ }^{6}$ Over the course of the second half of the Cold War, human rights became a rallying cry for a diverse range of NGOs, activists and social movements while also becoming institutionalized in U.S. foreign policy. ${ }^{7}$ Although historians have increasingly moved into the 1980 s, the role of human rights in the 1980 election remains relatively uncharted territory. ${ }^{8}$

This article represents the first comprehensive study of the role of human rights in the 1980 U.S. presidential election. To set the scene for the 1980 election, the article opens by tracing the emergence of human rights concerns in U.S. foreign policy from congressional activism through Carter's human rights based-foreign policy. It then examines the role of human rights in the foreign policy visions of the presidential candidates for the 1980 election, focusing especially on Reagan's criticism of Carter's human rights policy. Finally, the article assesses the impact the issue of human rights had on the 1980 election and the way the 1980 election shaped the role of human rights in U.S. foreign policy. In doing so, the article contributes to our knowledge of foreign policy in presidential elections as well as to the history of human rights in American foreign relations.

\section{America's Embrace of Human Rights}

The prominence of the concept of human rights in the 1980 presidential election was a remarkable development. Although the Carter presidency established human rights as the key moral language in debates on U.S. foreign policy, the concept was marginal to his campaign and not feature prominently in the 1976 election. ${ }^{9}$ In previous presidential elections the issue of

6 Samuel Moyn, The Last Utopia: Human Rights in History (Cambridge, MA: Harvard University Press, 2010).

7 Sarah B. Snyder, Human Rights Activism and the End of the Cold War: A Transnational History of the Helsinki Network (Cambridge, UK: Cambridge University Press, 2011); Barbara J. Keys, Reclaiming American Virtue: The Human Rights Revolution of the 1970s (Cambridge, MA: Harvard University Press, 2014); Mark Philip Bradley, The World Reimagined: Americans and Human Rights in the Twentieth Century (Cambridge, UK: Cambridge University Press, 2016); Sarah B. Snyder, From Selma to Moscow: How Human Rights Activists Transformed U.S. Foreign Policy (New York: Columbia University Press, 2018).

8 For a brief examination, see Rasmus Sinding Søndergaard, Reagan, Congress, and Human Rights: Contesting Morality in US Foreign Policy (Cambridge, UK: Cambridge University Press, 2020), 20-27.

9 Keys, Reclaiming American Virtue, 214-15. 
human rights had been further relegated to the margins of foreign policy debates if it had been mentioned at all. Thus, the 1980 election marked the first time human rights concerns played a key role in a U.S. presidential election.

Although it was Carter's presidency that elevated human rights to the center stage of the national debate, the breakthrough of human rights happened in the preceding years in Congress. During the second Nixon administration, human rights became part of a congressional assertiveness on foreign policy that generated substantial conflict between the executive and legislative branches of government. ${ }^{10}$ Rising in opposition to what they perceived as the imperial presidency of Richard Nixon, members of Congress passed a number of measures to restrict the presidency's prerogatives on foreign policy. These measures included the War Powers Resolution of 1973, which limited the president's power to deploy military forces without congressional consent as well as legislation that tied elements of U.S. foreign relations with other countries' their records on human rights.

Over the course of a five-year period starting in 1973, the liberal Democratic Representative Donald M. Fraser (D-MN) used his House subcommittee to hold a series of hearings on human rights issues that resulted in legislation that conditioned foreign aid and trade relations to the respect for human rights. Congress also passed several country-specific measures that cut off or reduced assistance to specific countries, including Argentina, Chile, El Salvador, the Philippines, South Korea, and Uruguay. ${ }^{11}$ The conservative Democratic Senator Henry "Scoop" Jackson (D-WA) introduced the Jackson-Vanik Amendment, which prohibited the granting of most-favored-nation status and trade credit to communist countries that denied or restricted the right to emigration. ${ }^{12}$ Fraser's subcommittee also published a report calling for the United States to take the lead on international human rights and detailing twenty-nine recommendations for integrating human rights concerns in U.S. foreign policymaking. ${ }^{13}$ Under growing congressio-

10 Robert David Johnson, Congress and the Cold War (New York, NY: Cambridge University Press, 2006), 190-241.

11 Stephen B. Cohen, "Conditioning U.S. Security Assistance on Human Rights Practices," American Journal of International Law 76, no. 2 (1982): 254.

12 Robert Gordon Kaufman, Henry M. Jackson: A Life in Politics (Seattle: University of Washington Press, 2000), 266-83.

13 United States, Human Rights in the World Community: A Call for U.S. Leadership (Washington, DC: U.S. Government Printing Office, 1974); Barbara J. Keys, "Congress, Kissinger, and the Origins of 
nal pressure, the executive branch accommodated several of these recommendations, including the establishment of a Human Rights Bureau at the State Department in 1975, the assignment of human rights officers to all its regional bureaus and compliance with a request for annual reports on the human rights situation in countries receiving U.S. aid. ${ }^{14}$ This congressional activism on human rights formed the backdrop to Carter's human rightsbased foreign policy.

To Carter, human rights represented a moral language to reclaim America's sense of virtue and a new guideline for the country's role in the world in the aftermath of the Vietnam War. ${ }^{15}$ Moreover, Carter's human rights based-foreign policy was aimed at resetting America's relations with the world by transcending Cold War contestation and improving relations with specific regions such as Latin America. ${ }^{16}$ In relations with the Soviet Union, Carter pursued human rights issues in an unsteady combination with support for improvements in superpower relations known as détente. ${ }^{17}$ In relations with the Global South, Carter's human rights-based foreign policy dictated criticism of authoritarian regimes but restraint from intervention. It also shaped the response to the demands of developing countries for a reordering of international economic relations through the so-called New International Economic Order. ${ }^{18}$

Human Rights Diplomacy,” Diplomatic History 34, no. 5 (2010): 823-51; Sarah B. Snyder, ““A Call for U.S. Leadership": Congressional Activism on Human Rights*," Diplomatic History 37, no. 2 (2013): 372-97.

14 The country reports were later expanded to include all countries, made public and greatly improved. Judith Innes de Neufville, "Human Rights Reporting as a Policy Tool: An Examination of the State Department Country Reports," Human Rights Quarterly 8, no. 4 (1986): 681-99; Rasmus Sinding Søndergaard, "'A Positive Track of Human Rights Policy’: Elliott Abrams, the Human Rights Bureau and the Conceptualization of Democracy Promotion," in The Reagan Administration, the Cold War and the Transition to Democracy Promotion, ed. William Michael Schmidli and Robert Pee (New York, NY: Palgrave Macmillan, 2019), 31-50.

15 Schmitz and Walker, "Jimmy Carter," 113-43; Campbell Craig and Fredrik Logevall, America's Cold War: The Politics of Insecurity (Cambridge, MA: Harvard University Press, 2009), 292-95.

16 This aim was illustrated by Carter's unprecedented decision to supplement his inaugural address with a recorded speech addressing the world. Jimmy Carter, United States Foreign Policy Remarks to People of Other Nations on Assuming Office, January 20, 1977. Online by Gerhard Peters and John T. Woolley, The American Presidency Project (accessed August 7, 2019), www.presidency.ucsb.edu/node/242950.

17 Umberto Tulli, A Precarious Equilibrium: Human Rights and Détente in Jimmy Carter's Soviet Policy (Manchester, UK: Manchester University Press, 2020).

18 Schmitz and Walker, "Jimmy Carter," 113-43; William Michael Schmidli, "“The Most Sophisticated Intervention We Have Seen": The Carter Administration and the Nicaraguan Crisis, 1978-1979," Diplo- 
In his inaugural address on January 20, 1977, Carter spoke of a new global demand for human rights: "The world itself is now dominated by a new spirit. People more numerous and more politically aware are craving, and now demanding, their place in the sun - not just for the benefit of their own physical condition, but for basic human rights." Consequently, he proclaimed that the United States' commitment to human rights had to be absolute and explained that, "Because we are free, we can never be indifferent to the fate of freedom elsewhere. Our moral sense dictates a clear-cut preference for those societies which share with us an abiding respect for individual human rights." $"$ The human rights record of other countries would affect the relationship between these and the United States.

Despite this forceful rhetoric, Carter was actually a relative latecomer to the cause of human rights. Unlike early human rights proponents, Carter opposed the Jackson-Vanik Amendment, arguing that it was an ill-advised interference in Soviet domestic affairs and his 1975 memoir did not mention human rights at all. ${ }^{20}$ As historian Barbara J. Keys has pointed out, Carter's religious beliefs and his interpretation of the civil rights movement made him predisposed to a moralistic foreign policy, but he was slow to adopt human rights language and only did so because he found that it resonated with the American public. Influenced by theologian Reinhold Niebuhr's Christian realism, Carter believed the world could not be cleared of injustice but that particular wrongs could be corrected - a worldview that fit well with the limited agenda of human rights. As a Southerner supportive of desegregation, Carter also believed that external coercion from the federal government had helped white Southerners to confront their past without losing face - a belief that would inform his approach to promoting human rights abroad. ${ }^{21}$

The first president to seriously grabble with how to make human rights concerns part of U.S. foreign policy, Carter experienced significant difficulties implementing rhetoric into actual policy. Despite the talk of an absolute commitment to human rights, the administration quickly determined

macy \& Statecraft 23, no. 1 (2012): 66-86; Michael Franczak, "Human Rights and Basic Needs: Jimmy Carter's North-South Dialogue, 1977-81,” Cold War History 18, no. 4 (2018): 447-64.

19 Jimmy Carter, Inaugural Address, January 20, 1977. Online by Gerhard Peters and John T. Woolley, The American Presidency Project (accessed August 7, 2019), www.presidency.ucsb.edu/node/241475.

20 Jimmy Carter, Why Not the Best? (Nashville: Broadman Press, 1975).

21 Keys, Reclaiming American Virtue, 231-41. 
that human rights would have to be pursued on a case-by-case basis and in combination with other national interests. ${ }^{22}$ In February 1978, Carter issued Presidential Directive 30 (PD30), which formally defined U.S. policy on human rights, emphasizing a preference for positive inducements through the allocation of foreign aid rather than economic sanctions. ${ }^{23}$ Regarding the question of which human rights to promote, the administration initially declared its intention to advance a broad spectrum of human rights divided into three categories: the integrity of the person, civil and political rights, and basic human needs. However, significant differences existed in the administration over the relative importance of these rights and ultimately Carter prioritized speaking out against torture, political imprisonment and other repressive practices while largely ignoring socio-economic needs. ${ }^{24}$

The administration's attempt to pressure authoritarian allies and the Soviet Union to improve their human rights records, while also improving U.S. relations with the Global South and continuing détente, meant that the human rights policy was never absolute. Human rights were pursued as a low-cost moral infusion to U.S. foreign policy but when it meant trouble, the administration was reluctant to pay the costs. ${ }^{25}$ Following the Soviet invasion of Afghanistan in December 1979 and domestic criticism of his foreign policy, Carter took a tougher approach to the Cold War. The invasion of Afghanistan effectively destroyed détente and the overthrow of U.S.friendly regimes in Teheran and Managua by forces hostile to the United States demonstrated the risks of criticizing authoritarian allies. Carter responded by hardening his rhetoric toward the Soviet Union, declaring that the United States would use military force if necessary, to defend its national interests in the Persian Gulf against further Soviet advances. ${ }^{26}$ The United States also withdrew from the Strategic Arms Limitations Treaty II (SALT II) negotiations and boycotted the 1980 Moscow Olympics. In July

22 Schmitz and Walker, "Jimmy Carter," 122-23. Foreign Relations of the United States, 1977-1980, Volume II, Human Rights and Humanitarian Affairs, (Washington DC: U.S. Government Printing Office 2013), Document 46.

23 Foreign Relations of the United States, 1977-1980, Volume II, Human Rights and Humanitarian Affairs, (Washington DC: U.S. Government Printing Office 2013), Document 119

24 Hauke Hartmann, "US Human Rights Policy under Carter and Reagan, 1977-1981," Human Rights Quarterly 23, no. 2 (2001): 405-12.

25 Ibid., 413-14.

26 Jimmy Carter, "State of the Union Address," https://www.jimmycarterlibrary.gov/assets/documents/ speeches/su80jec.phtml. January 23, 1980 (accessed December 30, 2019). 
1980, Carter signed Presidential Directive 59, which called for a build-up in nuclear weapons. ${ }^{27}$ Nevertheless, public perceptions that the United States was experiencing a decline in military power and that Carter was weak on foreign policy persisted.

The collapse of détente also destroyed the centrist consensus on national security among Democrats and moderate Republicans that had stretched from Nixon to Carter. This breakdown deepened divisions over foreign policy among Democrats and fostered a new unity in the Republican Party around a foreign policy of conservative internationalism. ${ }^{28}$ This new Republican foreign policy consensus was also a result of internal struggles in the party. During the 1976 Republican primary, conservatives had criticized President Gerald Ford's foreign policy of détente for ignoring human rights abuses in the Soviet Union. Although Ford won the nomination, by the end of the convention a conservative approach to human rights emerged triumphant. This approach defined human rights narrowly as civil and political rights and applied these to a strategic and ideological framework of anticommunism. ${ }^{29}$ In the following years, the rightward move was further fueled by the rise of the New Right and the migration of neoconservatives from the Democratic Party to the Republican Party. ${ }^{30}$ Several of these neoconservatives would occupy important positions in the Reagan administration, while others provided ideological support from through advocacy groups like the Committee on the Present Danger and the Committee for the Free World. ${ }^{31}$ The collapse of détente, the shift in party alignments as well as Cart-

27 The White House, "Presidential Directive/Nsc-59 Nuclear Weapons Employment Policy," https://www. jimmycarterlibrary.gov/assets/documents/directives/pd59.pdf. July 25, 1980 (accessed December 30, 2019).

28 Julian E. Zelizer, "Conservatives, Carter, and the Politics of National Security," in Rightward Bound: Making America Conservative in the 1970s, ed. Bruce J. Schulman and Julian E. Zelizer (Cambridge, MA: Harvard University Press, 2008), 265-87; Mason, "The Domestic Politics of War and Peace," 25354; Henry R. Nau, Conservative Internationalism : Armed Diplomacy under Jefferson, Polk, Truman, and Reagan (Princeton, NJ: Princeton University Press, 2013). According to Nau, conservative internationalism seeks to spread freedom, arm diplomacy, and preserve national sovereignty.

29 Daniel Sargent, A Superpower Transformed: The Remaking of American Foreign Relations in the 1970s (Oxford: Oxford University Press, 2015), 224-25; Bon Tempo, "Human Rights and the U.S. Republican Party," 151-58.

30 Justin Vaïsse, Neoconservatism: The Biography of a Movement (Cambridge, MA: Harvard University Press, 2010), 180-97; Michael Schaller, Right Turn: American Life in the Reagan-Bush Era, 1980-1992 (New York: Oxford University Press, 2007), 27-48.

31 Rasmus Sinding Søndergaard, "The Committee for the Free World and the Defense of Democracy" Journal of Cold War Studies (forthcoming), Vai" sse, Neoconservatism, 180-97. 
er's emphasis on human rights abuses in Latin America created a situation where the administration's human rights policy was criticized from both left and right. Leading liberal Democrats criticized Carter for failing to take an equally tough approach to right-wing dictators in countries elsewhere with a higher geostrategic importance to the United States such as South Korea and the Philippines. Conversely, conservatives and Cold War hawks blamed Carter's human rights policy for undermining American allies in Latin America and demonstrating a weakness that emboldened Soviet expansionism..$^{32}$ Carter thus went into the 1980 campaign with his human rights-based foreign policy beleaguered by both flanks.

\section{Human Rights in the 1980 Presidential Election}

Although domestic economic problems such as high inflation and unemployment rates dominated the 1980 presidential election, foreign policy, including human rights issues, also received considerable attention. ${ }^{33}$ The ongoing Iran hostage crisis after Iranian students took 52 Americans hostage at the American embassy in Tehran on November 4, 1979, in particular, drew attention to foreign affairs. The hostage crisis emerged in the aftermath of the Iranian Revolution, in which the U.S.-backed Shah was overthrown in favor of an Islamic republic under the leadership of Ayatollah Khomeini. Other key developments that drew attention to foreign policy included the Soviet invasion of Afghanistan, advances by Soviet-supported guerrillas in Ethiopia, Angola, and Mozambique, and the overthrow of the U.S.-friendly Anastasio Somoza in Nicaragua by the leftwing Sandinistas in July 1979. The combination of these foreign policy woes and the economic crisis fed a growing sense among many Americans that the United States was in decline.

32 William Michael Schmidli, The Fate of Freedom Elsewhere: Human Rights and U.S. Cold War Policy toward Argentina (Ithaca, NY: Cornell University Press, 2013), 163. For contemporary examples, see Jeane J. Kirkpatrick, "Dictatorships and Double Standards," Commentary 68, no. 5 (1979): 34-45, Robert W. Tucker, "America in Decline: The Foreign Policy of "Maturity," Foreign Affairs 58, no. 3 (1980): 449-84, Norman Podhoretz, "The Present Danger," Commentary 69, no. 3 (1980): 27-40.

33 Stephen Hess and Michael Nelson, "Foreign Policy: Dominance and Decisiveness in Presidential Elections," in The Election of 1984, ed. Michael Nelson (Washington, DC: Congressional Quarterly Press, 1985), 143; James T. Patterson, Restless Giant: The United States from Watergate to Bush V. Gore (New York: Oxford University Press, 2005), 148. In 1980, the average inflation rate was as high as 13.5 percent, unemployment reached 8 percent and interest rates soared to 18.5 percent. 
Carter's weakness emboldened Senator Edward M. Kennedy (D-MA) challenge the incumbent for the Democratic Party's nomination. Representing the leftist wing of the party, Kennedy was one of the leading liberal critics of Carter's human rights policy. Years before Carter's embrace of human rights, Kennedy had been one of the leading figures in the congressional human rights activism in the mid-1970s. ${ }^{34} \mathrm{He}$ was at the forefront of banning military aid to Augusto Pinochet's Chile in 1976 and two years later he successfully introduced an amendment to cut off military aid and commercial sales to Argentina over the military junta's human rights abuses. ${ }^{35}$ The Democratic primary thus stood between two candidates who both claimed the mantle of human rights.

Kennedy announced his campaign shortly after the onset of the Iran hostage crisis and in December 1979, he implicitly criticized Carter for his support for the Shah. In a television interview, Kennedy said that the Shah "ran one of the most violent regimes in the history of mankind - in the form of terrorism and the basic and fundamental violations of human rights, in the most cruel circumstances, to his own people." 36 The comments drew immediate backlash from both Democrats and Republicans, who rebuked Kennedy for sowing division at a time of national crisis and accused him of hurting ongoing efforts to secure American hostages. In this case, Kennedy's idealistic approach of consistently criticizing human rights abuses regardless of U.S. national interests backfired.

Despite this misstep, Kennedy proved a strong challenge to Carter's reelection, highlighting Carter's weakness. The brother of former President John F. Kennedy, Edward Kennedy enjoyed the benefits of name recognition and strong backing among Democrats. Although, Carter eventually persevered, he did not secure his party's nomination until the Democratic National convention August 1980. During the Democratic Primary he had been defeated by Kennedy in states such as New York, Pennsylvania, and California. Carter had moved to 'the right' on foreign policy following the heating up of the Cold War and domestic criticism from conservatives. Yet, as evident by Kennedy's challenge, this move made him vulnerable to criti-

34 Schmidli, The Fate of Freedom Elsewhere, 73-75; Keys, Reclaiming American Virtue, 140, 150-158; Snyder, From Selma to Moscow, 111, 122-123.

35 Snyder, From Selma to Moscow, 129-30; Schmidli, The Fate of Freedom Elsewhere, 81.

36 B. Drummond Ayres Jr., "Kennedy, after Criticizing Shah, Supports Carter's Efforts on Iran," The New York Times, December 4 1979, A1. 
cism from the left. On a more general level, Carter was hampered by a poor economy and the perception that he was a weak and ineffectual leader. Kennedy's challenge inflicted divisions in the Democratic Party and underlined Carter's weakness ahead of the general election. ${ }^{37}$

Whereas Carter experienced an unusually tough nomination challenge for an incumbent president, Reagan won the Republican primary in a much more convincing fashion. Having narrowly lost the 1976 Republican nomination to Ford, Reagan had a lock on the 1980 nomination early on. The two-term California governor and former Hollywood actor had become a conservative icon and despite contemporary arguments that he was too radical to win the presidency, Republican voters favored him over more moderate alternatives. He subsequently secured party unity by making his main opponent, the more moderate George $\mathrm{H}$. W. Bush, his running mate. In his acceptance speech at the Republican National Convention, Reagan emphasized his commitment to peace, but he also criticized Carter's record on the economy and foreign affairs, complaining that the Iran hostage crisis ridiculed the United States before the world..$^{38}$

The 1980 Republican Party platform adopted at the convention also launched a full-scale attack on Carter's human rights policy, arguing that Carter had been too tough on America's allies while failing to crack down on communist human rights offenders such as the Soviet Union, Vietnam, and Cuba. "The nations of South and Central America," the platform declared, "have been battered by the Carter administration's economic and diplomatic sanctions linked to its undifferentiated charges of human rights violations." ${ }^{39}$ Specifically, the platform lamented Carter's failure to prevent the Sandinista coup against Somoza in Nicaragua. The platform promised that a Republican president would rectify Carter's policy on Nicaragua by countering Soviet influence in the country and supporting "a free and independent government." 40 The Democratic Party platform, on the contrary, proclaimed the party's continued commitment to Carter's human rights

37 Mason, "The Domestic Politics of War and Peace," 258.

38 Ronald Reagan, Address Accepting the Presidential Nomination at the Republican National Convention in Detroit, July 17, 1980. Online by Gerhard Peters and John T. Woolley, The American Presidency Project, https://www.presidency.ucsb.edu/node/251302 (accessed January 3, 2020).

39 Republican Party Platforms, Republican Party Platform of 1980, July 15, 1980. Online by Gerhard Peters and John T. Woolley, The American Presidency Project, https:/www.presidency.ucsb.edu/node/273420 (accessed January 3, 2020).

40 Ibid. 
policy, stressing the need to be vigilant on human rights violations among allies as well as among enemies." ${ }^{41}$ Reagan and Carter thus emerged from the primaries with strongly opposed views on the appropriate role of human rights concerns in U.S. foreign policy.

Both Carter and Reagan believed that foreign policy represented a weakness for the other, leading them to focus on international affairs during the campaign. Beset by economic problems at home, Carter viewed foreign policy as a more promising case for reelection. ${ }^{42}$ Central to this strategy was the Carter campaign's belief that Reagan's lacking foreign policy experience and his reputation as a Cold War hardliner made him vulnerable in the area of foreign policy. During the campaign, Carter repeatedly painted a picture of Reagan as a dangerous warmonger who would cause war with the Soviet Union, framing the election as a choice that would determine "whether we have war or peace." ${ }^{43}$ Essentially, Carter's strategy sought to frighten the electorate about Reagan rather than to vindicate the president's record.

The Reagan campaign, conversely, believed that it could exploit the growing perception that Carter was weak on foreign policy and that the international standing of the United States was on the decline. Attacking Carter's approach to human rights figured prominently in this strategy. In 1978, Reagan had described Carter's human rights-based foreign policy as "well-meaning intentions" mixed with a "false sense of guilt" after Vietnam, but by 1980 he struck an even harder line. ${ }^{44}$ Despite Carter's alterations to his human rights policy, the Reagan campaign maintained that the Carter administration was too soft on the Soviet Union and too tough on American allies. In October 1980, an aide to the Reagan campaign claimed that a Reagan administration would transform the human rights theme into an instrument to counter Soviet propaganda. ${ }^{45}$

41 Democratic Party Platforms, 1980 Democratic Party Platform, August 11, 1980. Online by Gerhard Peters and John T. Woolley, The American Presidency Project, https:/www.presidency.ucsb.edu/ node/273253 (accessed January 3, 2020).

42 Mason, "The Domestic Politics of War and Peace," 251.

43 Edward Walsh, "Carter to Return to 'Peace or War' Issue," The Washington Post, September 28, 1980, Nexis Uni, Lou Cannon and Edward Walsh, "War, Peace Dominate Debate War and Peace Theme Dominates Carter-Reagan Debate," The Washington Post, October 29, 1980, Nexis Uni.

44 Peterson, Globalizing Human Rights, 107.

45 Richard Burt, "Presidential Candidates Stake out Divergent Ground on Foreign Policy," The New York Times, October 19, 1980. 
During the only presidential debate between the two major candidates on October 28, 1980, only a week before the election, Reagan attacked Carter for criticizing the human rights abuses of allies while at the same time seeking détente with the Soviet Union. Reagan lamented that Carter's policy toward allied authoritarian regimes had "in a number of instances, aided a revolutionary overthrow which results in complete totalitarianism." ${ }^{46}$ Arguing that Carter's human rights policy had "undercut our friends," Reagan blamed Carter for the fall of American allies such as Somoza in Nicaragua and the Shah of Iran. ${ }^{47}$ Reagan's arguments closely resembled those presented by Jeane Kirkpatrick in an influential article in the neoconservative journal Commentary the previous year. According to Kirkpatrick, Carter's human rights policy had neglected the centrality of the Cold War by failing to make a distinction between totalitarian communist regimes and authoritarian regimes. The former, she argued, were the ultimate human rights offenders for which there was no hope of reform, while the latter had the potential to democratize. Consequently, the United States should resist communism at all costs and support friendly authoritarians - a policy that became known as the Kirkpatrick Doctrine. ${ }^{48}$ By attacking Carter's human rights policy amidst perceptions of American decline, Reagan sought to paint a picture of Carter as a weak leader who failed to support America's allies and was unable to withstand communist aggression and Islamic fundamentalism.

Reagan also sought to link America's foreign policy troubles with its domestic economic problems. In his final statement during the presidential debate, he addressed the sense of decline by urging the American people to ask themselves, "Are you better off than you were four years ago? Is it easier for you to go and buy things in the stores than it was four years ago? Is there more or less unemployment in the country than there was four years ago? Is America as respected throughout the world as it was? Do you feel that our security is as safe, that we're as strong as we were four years

46 Quoted in Jimmy Carter, Presidential Debate in Cleveland, October 28, 1980. Online by Gerhard Peters and John T. Woolley, The American Presidency Project (accessed August 7, 2019), www.presidency.ucsb. edu/node/217132.

47 James Peck, Ideal Illusions: How the U.S. Government Co-Opted Human Rights (New York: Metropoli$\tan$ Books, 2010), 85.

48 Kirkpatrick, "Dictatorships and Double Standards." Kirkaptrick would go on to be an influential figure in Reagan's foreign policy team, where she served as Ambassador to the United Nations. 
ago?"49 With Carter's so-called misery index (the combination of inflation and unemployment numbers) peaking at 20.76 in 1980 and the foreign policy embarrassments of Afghanistan and Iran fresh in mind, many Americans decided they could not answer Reagan's questions affirmatively. ${ }^{50}$

\section{How Human Rights Impacted the Election and the Election Impacted Human Rights}

Foreign policy, including human rights, was crucial to the 1980 election, which had a higher percentage of newspaper editorials devoted to foreign affairs than had the previous four elections. ${ }^{51}$ Foreign policy even received more newspaper coverage than domestic and economic issues combined.$^{52}$ Moreover, the study found that four foreign policy issues dominated the coverage: the Iran hostage crisis, the development of stealth aircraft, the SALT II negotiations with the Soviet Union, and the question of war and peace. The Iran hostage crisis, in particular, dominated the news cycle and was the favored topic for the newspapers front pages.$^{53}$ It also dominated evening news reports, which continually reminded viewers of the number of days the American hostages had been held captive. ${ }^{54}$ The coverage was further amplified just before the election, as Election Day fell on the oneyear anniversary of the taking of the hostages.

Furthermore, contemporary polls and studies indicated that while the economy was the most important issue for voters, foreign policy mattered a great deal to a large part of the electorate. In one study, 56 percent of voters sad the economy was the most important issue, but 32 percent answered foreign policy - a marked increase from a mere four percent in the previous

49 Presidential Debate in Cleveland, October 28, 1980. Online by Gerhard Peters and John T. Woolley, The American Presidency Project, www.presidency.ucsb.edu/node/217132 (accessed January 3, 2020).

50 United States Misery Index, (accessed August 2, 2019), www.miseryindex.us/indexbyyear.aspx.

51 David S. Myers, "Editorials and Foreign Affairs in Recent Presidential Campaigns," Journalism Quarterly 59, no. 4 (1982): 542. The study compared the editorials of ten leading newspapers in the months before the elections of 1964, 1968, 1972, 1976 and 1980.

52 James Glen Stovall, "Foreign Policy Issue Coverage in the 1980 Presidential Campaign," Journalism Quarterly 59, no. 4 (1982): 533-34. The study coded campaign events in 49 daily newspapers from September 3 to November 4 in 1980. Of the events concerned with policy issues the study found: 118 foreign affairs events, 62 domestic and 26 economic.

53 Ibid., 540.

54 Gil Troy, Morning in America: How Ronald Reagan Invented the 1980s (Princeton, NJ: Princeton University Press, 2005), 31. 
election. ${ }^{55}$ Foreign policy was decisive for the election because of the large differences between the candidates' foreign policies, including their views on human rights, as well as the high salience of certain foreign policy issues. ${ }^{56}$ First and foremost, it was the Iran hostage crisis that haunted Carter. Although the crisis initially benefitted Carter's popularity as the American people rallied behind their leader, the continued failure to secure the release of the hostages turned the issue against Carter. ${ }^{57}$ Reagan hit the issue hard as a prime example of his characterization of Carter as a weak president that undermined respect for the United States abroad. Carter's memoirs reveal that he believed the outcome of the hostage crisis could make or break his reelection bid, whereas the Reagan camp worried that a release of the hostages could provide the incumbent a last-minute popularity boost..$^{58}$ Tehran's decision to withhold the release of the hostages until the day after Reagan's inauguration more than anything underlined the way international affairs benefitted Reagan rather than Carter.

Carter's embrace of human rights likewise ended up hurting his bid for reelection. Initially, his promise to restore morality to U.S. foreign policy by making human rights a guiding principle for America's foreign relations had been popular. Opinion polls during Carter's tenure consistency showed public support for human rights as part of U.S. foreign policy. Asked to rate the importance of a list of foreign policy goals in November 1978, 39 percent answered that "promoting and defending human rights and democracy in other countries" was "very important" while 40 percent answered "somewhat important," and only 14 percent chose "not important." ${ }^{99}$ Yet, while public support for human rights persisted, Carter's specific human rights policies became less popular and contributed to the image of him as a weak and ineffectual president. In the context of Soviet expansionism and the fall of American allies such as Somoza in Nicaragua, his commitment to

55 Andrew Busch, Reagan's Victory: The Presidential Election of 1980 and the Rise of the Right (Lawrence, KS: University Press of Kansas, 2005), 130.

56 Hess and Nelson, "Foreign Policy: Dominance and Decisiveness in Presidential Elections," 143; John Aldrich, John Sullivan and Eugene Borgida, "Foreign Affairs and Issue Voting: Do Presidential Candidates "Waltz before a Blind Audience?"," The American Political Science Review 83, no. 1 (1989): 136.

57 Mason, "The Domestic Politics of War and Peace," 252.

58 Jimmy Carter, Keeping Faith: Memoirs of a President (London: Collins, 1982), 566; Richard Wirthlin and Wynton Hall, The Greatest Communicator: What Ronald Reagan Taught Me About Politics, Leadership, and Life (Hoboken, NJ: John Wiley \& Sons, 2004), 70-73.

59 Chicago Council on Foreign Relations. Gallup/CCFR Survey of American Public Opinion and U.S. Foreign Policy 1978, November 1978. USGALLUP.78CFR.R32L. Cornell University, Ithaca, NY: Roper Center for Public Opinion Research, iPOLL, accessed August 2, 2019. 
non-intervention and criticism of authoritarian regimes made him vulnerable to attacks that he was responsible for a decline in American power on the international stage.

Ultimately, Reagan won the election in an unexpected landslide, taking 489 electoral votes against Carter's 49. The popular vote amounted to 51 percent for Reagan, 41 percent for Carter and 6.6 percent for the independent candidate John B. Anderson. A conservative Republican turned moderate; Anderson had decided to run as an independent after finishing third in the Republican primary. The Republican Party also took control over the Senate for the first time since 1955 and decreased the Democratic majority in the House by 34 seats. However, a Reagan victory appeared far from a foregone conclusion in the months leading up to the election. Polls generally indicated a close race, and only one week before the election a Gallup poll among registered voters even gave Carter 47 percent of the votes to Reagan's 39 percent. ${ }^{60}$ Post-election polls indicated that an unusually high proportion of voters were undecided right until the end with as many as 37 percent making their decision during the last week. ${ }^{61}$

Historians as well as contemporary observers have characterized the 1980 election as a massive shift to the right in American politics and society. ${ }^{62}$ However, the landslide was less categorical than it appeared and Reagan's victory was not an indication of the American electorate enthusiastically embracing conservative ideology. ${ }^{63}$ In the year of conservatism's biggest triumph only 32 percent of Americans self-identified as conservative. ${ }^{64}$ Americans were clearly disgruntled with the malaise of the Carter years and desperate to try something new and the election result was as much a rejection of Carter as it was an embrace of Reagan. ${ }^{65}$ Reagan offered a refreshing optimism and a promise to restore Americans' confidence in themselves and their country. Still, Reagan's victory came during an election that had

60 "Late Upsets Are Rare, but Have Happened," Gallup, October 24-26, 1980, (accessed August 2, 2019) http://www.gallup.com/poll/111451/late-upsets-rare-happened.aspx.

61 Everett Carll Ladd, "The Brittle Mandate: Electoral Dealignment and the 1980 Presidential Election," Political Science Quarterly 96, no. 1 (1981): 9.

62 For contemporary examples, see David S. Broder, "A Sharp Right Turn," The Washington Post, November 6, 1980, 2. Hedrick Smith, "A Turning Point Seen," The New York Times, November 6, 1980, A1.

63 Troy, Morning in America, 49.

64 Cheryl Hudson and Gareth Davies, eds., Ronald Reagan and the 1980s: Perceptions, Policies, Legacies (New York: Palgrave Macmillan, 2008), 45.

65 Mason, "The Domestic Politics of War and Peace," 265. 
the lowest voter turnout since 1924 - only a little above 52 percent, reflecting the general lack of enthusiasm among the population. ${ }^{66}$ Thus, despite the considerable Republican electoral victory in 1980, there were limits to the conservative shift it signified in American society.

On foreign policy, however, the 1980s election did signify a rightward move with important implications for U.S. human rights policy. In 1976, yearning for a restoration of honesty and morality in American government and foreign policy in the slipstream of Watergate and the Vietnam War, American voters had chosen Jimmy Carter's message of a revitalized moralism. During the 1976 campaign, Carter famously told the American people that he would never lie to them and took a moralist approach to foreign affairs that would eventually be articulated in human rights language. ${ }^{67}$ Four years later in 1980, beset by economic crisis and perceptions of American decline under a weak president, American voters opted for another promise of restoration. This time, however, the restoration was Reagan's message of economic growth and renewed American strength in world affairs. The role of human rights in American foreign relations had also changed. Whereas Carter had embraced human rights as tool to distance the United States from repressive allies and an attempt to move beyond the Cold War through a policy of restraint, Reagan incorporated human rights into a more interventionist and assertive foreign policy aimed at defeating communism once and for all.

\section{Conclusion}

Foreign policy played an unusually large role in the 1980 U.S. presidential election, which took place in the shadow of the ongoing Iran hostage crisis and the Soviet invasion of Afghanistan. Human rights, which had never previously been given any serious attention in presidential elections, also suddenly stood at the center of the debate about U.S. foreign policy. Carter's human rights-based foreign policy, adopted in the aftermath of congressional activism on the matter, made human rights a core concept in Carter's bid for reelection as well as in Reagan's attack on the incumbent. Informed by different worldviews, Carter and Reagan envisioned markedly dissimilar roles for human rights in U.S. foreign policy. Whereas Carter's

\footnotetext{
66 Douglas Brinkley, The Unfinished Presidency: Jimmy Carter's Journey Beyond the White House (New York: Viking, 1998), 3.

67 Keys, Reclaiming American Virtue, 214-41.
} 
embraced human rights to rehabilitate the international image of the United States and move beyond Cold War contestation, Reagan selectively employed human rights as an ideological weapon to defeat the Soviet Union.

Foreign policy, including human rights, thus shaped the 1980 election, but the election also impacted the role of human rights in American foreign policy in the years to come. Reagan entered the White House highly skeptical of human rights as a foreign policy concern. A human rights-based foreign policy, as practiced by Carter, was both practically and ideologically incompatible with Reagan's conservative internationalism, and the administration's initial reaction, once in office, was to dismiss human rights concerns altogether. Despite this initial skepticism, within Reagan's first year in office pressure from members of Congress and the wider human rights community led the administration to revise its position on human rights. The result became a conservative human rights policy that integrated human rights concerns into the administration's broader foreign policy vision for combatting communism and selectively promoting democracy. ${ }^{68}$ As the event that facilitated this conservative human rights policy, the 1980 election stands as a watershed moment in the history of American attention to human rights. 